\title{
If a Tree Falls in the Forest: The Role of Community Formation and the Power of the Individual in Zine Making Participation
}

\section{Peter Bryant, London School of Economics, UK}

\begin{abstract}
Zine making is a complex practice, rich in parallel traditions and historical engagement in a number of vocal creative and social communities. Drawing on data from thirty-two depth interviews conducted in Australia, Europe and the United States, this study was concerned with the question of whether the processes of identification and articulation into a community were critical to the decision by an individual to make zines and to what extent does the community influence these individuals as they engage in zine making practice? We found that although personal reasons for zine making were explicitly described by a number of respondents, there were few examples where altruistic community engagement was explicitly cited. There was also significant porosity between any discussion of community and the role that person played or sought from it.
\end{abstract}

Keywords: Zines, zine making, alternative media, community formation, participation 


\section{Introduction}

Zines are a unique medium that have survived (and some would argue flourished) over nearly eighty years of production, unlike many other similar media forms in an environment of ubiquitous social media and declining print circulations (Angel \& Kucsma, 2004; DeSousa, 2008; Young \& Collins, 2010). Zine making is a contested and sometimes contrary practice informed by an impassioned and analytical debate that has frequently coalesced around the future of zines in a social media world, the rationale and motivations for participation and the role of zine making in forming and informing communities (Brown \& Duguid, 1996; Lankshear \& Knobel, 2010; Malekoff, 2010). The notion of participation exposes significant tensions within these debates centring on the role of the individual, their connections with readers, the distinctiveness of different zine typologies and the status of the wider community in zine making (Piepmeier, 2008).

Zine making is a process that can occur within a community or undertaken by an individual or a small collective, either actively as members or passively as outsiders, looking in. The definitions of behaviour, practice and what it means to be a zine maker can be argued to be socially constructed and community owned (Duncombe, 1997). Through the lens of this process, the relationship of the zine maker to their community can often be quite fractured, and the role of the zine itself can vary from change agent to an instrument of codification to an organ of expression (Collins, 1999). The connections formed within and between these communities occur not just through physicality and proximity but through meaning and embodiment, where the ephemera of production and materiality form 'intimate, affectionate connections' (Piepmeier, 2008, p. 214). Eichhorn(2001) notes that this sense of community is an important motivation for zine makers and zine readers, arguing that '... while many' zine producers are less reliant on 'zine networks for support, for the majority of participants in my study the support and sense of community they encountered through the writing and distribution of 'zines was viewed as essential' (Eichhorn, 2001, p. 570). There are also significant tensions that arise from the contested notions of zines as a form of personal media. These debates coalesce around the concepts and importance of voice and expression to zine making practice. Are zines the voice of communication within under-represented communities? Do they seek to be idiosyncratic expressions of individuality and voice presented in amateur, rough DIY packages? (O'Neil, 2004; Peace, 2007; Piepmeier, 2009). These questions do not necessarily represent the critical absolutes within the debate, with 
these personal and political engagements blurring and mixing leaving the space between where sense-making and identity definition can occur (Blazek, 2006; Chu, 1997).

Within the context of print zine making practice, are the processes of identification and articulation into a community critical to the decision by an individual to make zines? To what extent does the community influence these individuals as they engage in zine making practice, either at the early or formative stage, or as a part of a decision to continue with the practice? Using data drawn from a series of email depth interviews with thirty-two zine makers in Australia, Europe and North America, the positionality and potential privilege afforded to the interactions between zine makers and their community is explored. Zines historically have played central roles in both the proliferation and popularisation of punk movements, with both the 1970s punk scene and the 1990s riot grrrl scene exposing zine making as a critical voice within their then-growing communities (Culton, 2007; Dunn \& Farnsworth, 2012; Gottlieb \& Wald, 2006; Moore, 2007; Triggs, 2006). Without the immediacy and rebellion extant in those movements, what conditions are imperative to ensure the sustainability of the medium and continued participation in zine making?

\section{Zine Making Participation and the Community}

The underlying definition of community in the context of zines is a relatively fluid one, both in terms of the specifics such as defining membership or scope (Cogan, 2007; Jackson, Herranz, \& Kabwasi-Green, 2003) and the wider concepts underpinning the 'sense' of community that is rooted in belonging and common meaning (Chavis, Hogge, McMillan, \& Wandersman, 1986). In the context of zine making, community may manifest itself as the interest or discipline-led aggregation of people for which the zine maker was or aspires to be a member of (Gordon, 2012; Steele, 2006). Alternately, a number of writers define community within the context of zine maker themselves as an instrument of community formation, where a network of people (readers, zine makers etc.) form around the publishing and distribution of a specific zine or zine series (Livingston-Webber, 1994; Rauch, 2007; Richardson, 1996). Neither of these represent complete or agreed definitions in that much of their meaning is inculcated within personal discourses and motivations for making zines (Chidgey, 2006; Ware, 2003). Whilst the focus of this research was on the importance and role of the community in the decision making process to make zines, not necessarily on the way the community itself was formed and managed, the definition of community within the literature 
was still critical in contextualising and analysing the experiences and opinions of zine makers in the study.

The shifting sands around the collective understanding of the notion of community are in line with much of the debates that have occurred in the literature about zine making practice. There is a considerable lack of unanimity around what constitutes a zine, the impact or importance of e-zines and blogs and the relative merit or value of the different types of zine content (Bartel, 2004; Duncombe, 1997; Sellie, 2005; Wrekk, 2005). A particularly relevant example can be demonstrated by the alternately recursive and iterative development of zine making, where new and emerging forms of zines are evolving alongside the previous forms (which continue to be produced and find audiences). This has led to a peripatetic understanding of zine making participation and of the position of zines as an instrument of community communication and/or individual expression. Broadly falling into two quite porous and non-mutually exclusive frames, zine making participation is often described strictly within the context of a specific zine form. The personal frame argues that personal experiences or the need for individual expression facilitates zine making participation (Collins, 1999; Piepmeier, 2008; Runte, 2000). This frame is especially porous as concurrent or subsequent behaviours can engage the zine maker in an existing or self-formed community (Duncombe, 1997; Rauch, 2004). At a more abstract level, there is an argument that zine maker in fact forms their own communities or has a community coalesce around them, either intentionally or incidentally as a result of making a zine (Eichhorn, 2001; Schilt, 2004; Zobl, 2004b). The community frame is where participation within a community occurs through the process of making a zine (Cogan, 2007; Harris, 2003; Licona, 2012; Spencer, 2005) or where the zine is made as part of a process of community information, identification or analysis (Boellstorff, 2004; Collins, 1999). The boundary is porous within this frame at the point of transition between reader and creator (Hamilton, 2000; Payne, 2009; Spencer, 2005). Some zine makers interviewed within other studies have represented the reader relationship in terms of their inter-personal interactions; sharing, informing or engaging with people of similar backgrounds, philosophies or experiences, which in effect represents community engagement through a process of individual expression (Piepmeier, 2009; Poletti, 2008; Schilt, 2003a; Sinor, 2003). 
This porosity makes the construction of generalisable observations about zine making participation problematic. The contradictions and complexities posed a number of critical questions that centred on the role of the community in the zine making decision process. What we were most interested in was the zine maker's perceptions of their own community and their role within it. Whilst trying to avoid the 'chicken or the egg' question about which came first; the decision to make zines or the membership of a community, we were inevitably drawn to questions of authenticity of experience within that community, the resonance of membership as an instrument of motivation and the relationship the zine maker had other with zine makers and readers and its influence on participation. At the core of this were the analogous arguments of the role of the collective or the individual in the decision making process. Whilst the outcome is the same (the zine being made) the evolution of participation could be markedly different.

For example, there is an argument made by some writers that zine makers can play an active role as a nexus around which a personal or support community forms (Eichhorn, 2001; Schilt, 2004; Zobl, 2004a). This role argues for the zine maker to actively engage with a self-formed community, facilitating the emancipatory dialogues, support networks, interactions and intimacy that mark zines as a unique and personal medium (Licona, 2012; Piepmeier, 2009; Poletti, 2008; Radway, 2011). The engagement with the community however is not necessarily at the start of the process. Community formation may occur as the zine maker distributes, markets and talks about their zine, often in informal settings and through activity rather than intention (Poletti, 2008). Alternately, the desire to form a community may be premediated, with examples of zine makers '...seek(ing) to build and mobilize community, and work(ing) to forge alliances across lines of difference for purposes of pursuing agendas that are framed in terms of social justice and equity' (Licona, 2005, p. 109). In other instances, the community can be formed around the media instrument as a form of interpretative community where the language and knowledge required to engage with the content ensure that the exclusive nature of the community remains (Cogan, 2007, p. 813). Often, much of this process is organic in that the zine maker, through the relatively passive methods of distribution and construction, hope to form a community through readers identifying and purchasing their zine. The intersection of the personal and the community in all these processes is fluid and yet subject to individual decisions and choices. 
Whether zine making is an active statement of an intent to rebel against the existing media pedagogies (Licona, 2005; Stern, 2001) or a passive model of speaking to an invisible audience' (Sutton, 1999) there is a tension around what kind of knowledge exists and whether information sharing remains the privilege of the individual zine maker (Ferris, 2001; Stoddart \& Kiser, 2004). It is the zine maker's personal engagement with experience, linked perhaps with the knowledge that someone else may have experienced something similar that can facilitate the engagement or formation of a community (Schilt, 2003b). Rauch (2004) notes that this engagement can be an interpretive one, resulting in the formation of '...informal contacts, shared discourse, and collective interpretations' (Rauch, 2004, p. 157). In such a dynamic environment, the entry of new members to a community may challenge the functions extant in the community or even re-invent and re-define the community itself through shifting the way community members are attracted and involved (Lacey, 2005; Milner, 2002; Sinor, 2003). At a far simpler level, this knowledge transferal can occur through the act of reading the zine, and may be entirely passive with reader never making contact with the zine maker but still feeling part of a community and feeling a connection with the zine maker (Duncombe, 1997; Piepmeier, 2008; Rosenberg \& Garafolo, 1998).

It is also difficult to separate the notions of community from experience. There is an argument made that the experiences, behaviours and influences of individuals are fundamental to their decision to participate in zine making (Duncombe, 1997; Freedman, 2009; Grant, 2009; Gunderloy, 1990; Holtzman, Hughes, \& Van Meter, 2007). Arguably, these decisions are equally predicated on the interactions, either directly or indirectly with zines made by others. Transitioning participation from consumption to production is a process actively supported by the community itself. Poletti(2005) argues that '...zine culture specifically challenges the distinction between readers and writers, encouraging people to create their own textual and/or visual products' (Poletti, 2005, p. 186), whilst Zobl (2004b) positions zines as a space where readers and writers coalesce to form communities or a '...supportive and safe space for like-minded peers willingly to share their experiences, thoughts and opinions with one another' (Zobl, 2004a, p. 159), either as a positive, reinforcing exposure (Eismann, Jiménez, \& Zobl, 2008) or in a negative 'I can do better' challenge (Zobl \& Jiminez, 2008). 


\section{Methodology}

This study drew on thirty-two semi-structured qualitative interviews conducted by email with zine makers in Australia, the United States, Canada, the Netherlands and the United Kingdom in 2010 and 2011. The respondents were selected using a purposive sampling approach, with expressions for participation placed on five different zine making websites, Facebook and three online zine mailing lists. The expressions of interest were then snowballed out through the first round of respondents, resulting in the final sample.

Within a larger set of questions, each respondent was asked some demographic questions on their geographic location, the number of zines they had made and to determine that they made print zines (as opposed to e-zines). The interview then discussed the zine maker's role (if any) in the wider communities they engaged with and how important these communities were to their decision to make (or continue to participate in making) zines. This was supported by a set of questions around the role of zines themselves in that community and the 'ideal' interaction between zine readers and makers. The intention of the framework of linked questions was to allow for multiple interpretations of the word 'community' that might occur and to probe meaning and understanding within that.

A content analysis was undertaken as a two-stage process using Hsieh and Shannon's (2005) summative content analysis approach, which allowed for the identification of key words against descriptors in the literature. This frame of analysis was applied to the data set in order to find the underlying meanings of the words used through interpretation. The literature and the data set were iteratively analysed, starting with word counts and progressing to more descriptive categorisation in the context of the surrounding text to identify latent meaning. The use of culture-specific words, the confessional style of some interviews and the more euphemistic or journalistic responses of others generally supported the use a textual check against the literature. This sought to ensure consistency of interpretation and enhance the credibility of the study, along with a careful analysis of the descriptors used in the frames described in the literature (Matthes \& Kohring, 2008; Weber, 1990).

It is important to note that there is no existing data to measure the size of the population of zine makers. It is a relatively transient group, where some individuals might make a single zine and never participate again and others who produce issues regularly. The relatively small 
circulation of most zines (Duncombe, 1997; Spencer, 2005) makes counting of the total number virtually impossible. The results from this study may have some scope for generalisation across zine making practice; however the difficulty in determining how representative the interviews were should be taken into account.

\section{Data Analysis}

All of the people interviewed were active zine makers, who had produced at least one zine in the past two years and had intentions of or were producing at the time of the interview, another zine. The sites where the survey was promoted are largely populated by people who broadly define zines as a print media and each interview started with a clarification that the zine maker produced and distributed primarily print zines. Each interviewee was asked to state their country of origin and the number of zines they had produced. Whilst we were making no assumptions as to the impact of factors such as location, in the initial data analysis process we did not cross-tabulate against the country of origin. There was a spread of locations in the sample (fourteen from Australia, eight from Europe and ten from North America). During the second stage of data analysis we isolated responses against location and identified no discernible differences, although it should be noted that all bar two responses came from zine makers who wrote in English. This might go some of the way towards explaining the unanimity between locations although this Anglophone bias (and lack of research and knowledge of non-English language zines) has been raised as significant issue in the on-going critical scholarship of zine making (lolagouine, 2009; Zobl, 2009).

Within the dataset the word 'community' (or communities) was used by zine makers fifty-two times. As the first question specifically focused on the relationship that zine maker had with the wider zine community this count was not surprising, although as a measure of comparison, the question asking about the relationship between the zine maker and their readers only elicited fourteen uses of the word 'reader'. The use of 'community' as a descriptor by the respondents varied wildly. This diversity is clearly aligned to a similar variation within the literature. At the second stage of coding, the notions of ownership and membership began to emerge within the wider context of the responses. It was quite clear when respondents claimed ownership of a community and this assertion was linked often explicitly to their decision to make zines. Equally, there was similar clarity where the 
respondents were defining their membership of a community which originated or occurred through the decision to make zines.

\section{The Role of Community in Decision Making}

There was some evidence of the porosity described in the literature between the personal frame and community frame of participation in zine making. A number of respondents $(n=8)$ made explicit references to the fact that whether there was a community formed or informed by their zine or not, they would still continue to make zines;

'I mistakenly thought that because I shared a common hobby/interest with others, and because I was interested in the zines that they made regardless of genre, that they would be interested in the zines I make. This clearly is not the case. At least, not in my experience. There are a lot of zinester cliques, and while I've found a few individuals that share my interests and values, I feel like an outsider, on the fringe, of the "zine community"' (R.4)

This was balanced by an almost equal number $(n=7)$ who argued that the community was critical to their motivations for making zines;

'My personal relationship with the wider zine making community is very important. Without them, no one would read or distribute my zine which would make the whole point of creating a zine kind of moot. If it wasn't for the community, these zines would just be web pages or blogs' (R.20)

However, the boundaries between these perspectives were not absolute, with some respondents arguing that the community (however this is defined by the respondent) played an important, though not necessarily essential, role;

'Now that I've been involved with a zine community for all of my adult life, it is something that is very important to me. I do think that without a zine community I would still continue to make zines, but I would probably just send them to friends and family.' (R.1) 
'I love that zine making is a community, but (aside from trading zines once in a while) I would not say that this is important to my zine-making practice. My relationship to the zine community is entirely separate from my practice as a zinemaker.' (R.5)

Three respondents argued that the role of the community shifted as their career in zine making progressed, highlighting the support and feedback gained from initial interactions and interestingly, the use of a zine as a 'ticket' into a community;

'The first zines I did were basically made so I could feel like a part of a punk community, a way to talk about political ideas, and part of my efforts to become one of the cool kids.' (R.10)

Underpinning these insights was the interests or self-interest of the maker themselves. In the first stage data analysis words signifying possession, ownership or individuality appeared frequently in the word count (' $\mathrm{I}=256$ ', ' $m y \mathrm{n}=97$ ', ' $\mathrm{me} n=24$ ' and 'mine $n=2$ '). Now clearly many of these instances were related to the specifically addressing the question asked. However, when we linked the possessive terms with the more descriptive notions of community within the responses, the personal benefits gained from community engagement were more apparent in the data than the altruistic, sometimes evangelical rationales suggested in the literature. Respondents clearly identified the benefits of engaging with the community by describing the support and friendship provided by other zine makers and the personal things they had to say to that community through stories ('friend $n=22$ ', 'personal $n=10$ ', 'stories/story $\mathrm{n}=5$ '), whilst the notions of zines as instruments of rebellion (Guzzetti \& Gamboa, 2004; Radway, 2011), reclaiming voice (Wagg, 2003; Wray \& Steele, 2001) or fighting disenfranchisement or oppression (Harris, 2004; Zobl, 2003) which were prevalent in the literature were not frequently observed in the data set ('rebellious or rebel $n=2$, voice $\left.\mathrm{n}=1^{\prime}\right)$. What emerged was a different interpretation of the position of the community, where a number of respondents $(n=5)$ clearly stated that these were not just their personal stories they but they (either stories or the zines) were owned by, and for the community; 
'I make zines to develop my writing skills and drawing skills but also in the hope that those skills will be recognised and that I may get hearback (sic) about it. But also to make friends and have fun with what I'm doing.' (R.2)

'SO my zine isn't just "my story" it is part of a rebellious fabric of society that is a movement for change' (R.13)

\section{The Community of Readers and Zine Makers}

Some of the respondents made very clear distinctions between people who read their zine and people who made zines that they themselves either successfully or unsuccessfully interacted with. Words such as 'feedback $(n=3)$ ', 'inspire $(n=4)$ ' and 'interact $(n=4)$ ' were used directly in relation to what they were seeking from making zines. The context round these words suggested that the reader was there as a form of validation for the content or design of the zine. Some respondents noted that they actively sought this kind of engagement as a precursor to continuing their involvement in zine making.

When talking about other zine makers, the respondents used words like 'sharing $(\mathrm{n}=6)$ ', 'support $(n=3)$ and 'collaborative $(n=3)$ '. This appeared to represent a more dialogue driven process, often described in the context of zine fairs for face-to-face interaction. Another concept that emerged was the perceived role of the zine maker to 'encourage' $(n=5)$ and 'inspire' others $(\mathrm{n}=3)$. The stories that the zine makers tell link their decision to make zines to a higher order motivation of providing a route to the participation of others through example and action. This transition or education process sits at the centre of zine making practice, as zines have been noted to act as blurring agent between cultural consumption and cultural production (Poletti, 2005).

However, in the majority of case these words were not explicitly used in relation to readers, other than where the line between readers and other zine makers was blurred;

'All zine readers should be zine makers. Also, we should send each other more creative challenges and feed off each other's interests and experiments. It is a creative community I seek in zines, rather than a writer-reader relationship.' (R.10) 
'My ideal would be that there is no difference or dividing line between zine makers and zine readers. I would like there to be more of both readers and makers (whatever their relationship to each other. I think there is danger in the zine community becoming stagnant, self-serving and inward looking (R.5)'

\section{Defining Community through the Decision To Make Zines}

There was significant evidence to suggest that the decision to makes zines was strongly connected to the intention to form a community with the zine maker at the centre. This was described primarily as a community of readers, which communicated with the zine makerafter they had purchased or obtained the zine. There was a distinction drawn between readers that they zine maker already knew in this context (family, friends) and new readers, which were an often unknown quantity. There were a number of zine makers who pointed to already existing communities and their intentions or desires to be become a part of them ('part $n=14$ ' and 'member $n=3$ ). These words were used to describe the relationships sought by zine makers as a result or function of making a zine.

The ease of entry into these desired communities was critical for a number of respondents in deciding to engage in zine making. At one end was the altruistic notion, that by choosing to make zines they were engaging and perhaps demonstrating that there was a larger world of connected people out 'there' $(n=5)$. This was supported by their intention to create a place where they and their community could share, talk and express themselves freely $(n=3)$, which is some cases manifested itself as the exertion of some form of ownership or proprietorial interest ('my community $\mathrm{n}=3$ '). One respondent defined their 'ownership' of their community in clearly personal terms;

'By community I'm referring to the people I've interacted with, that network that's concentrated in my home town but spreads in dribs \& drabs across the country \& a few spots overseas.' (R.15)

Alternately, a number of respondents rejected the definition of zine communities as welcoming and supportive $(n=6)$, and that they made zines for themselves or as a platform for the way they wanted the audience to think and act. In some instances they found themselves 
as unwitting though not necessarily unwilling community members by default as opposed to intention;

'I increasingly feel that I speak only for myself, and that zines have been a fantastic way for me to pare back all the other stuff and find my own voice. But I do feel that making zines makes me part of a creative community with its own energy and interests, some of which overlap with mine and some of which bore me' (R.8)

'We do produce a lot of socio-political satires but essentially see ourselves as individuals and artists. We do not conform or belong to any specific religious or sociopolitical group. We mainly represent a part of the counterculture that stands for unconditional freedom of artistic expression, no boundaries; no censorship' (R.17)

The fuzziness with which community was defined by the respondents (two respondents referred to idea of seeking to engage with an 'unknown' community in their decision making process) was interesting in that across a number of the analytical categories there was a lack of certainty about who might read the zine, who the community was, what the zine was really about or who is was written for. The uncertainty may be interpreted as a lack of commitment to the medium or a different perspective on the role of the zine to facilitate entry to a community and could suggest further research into the strength of the decision made to make zines. Much of this speculation was succinctly summarised in an experience had by R.18;

'A girl sent me a zine that was obviously slapped together with a note reading "I just threw this together so I would have something to trade" it made me really angry that I would spend months working on a zine and this person just threw some thing together to get an unequal trade. So, I wrote her to let her know what I thought and apparently she was really angry at me about it.' (R.18)

\section{The Role of the Individual}

There were a number of responses $(n=6)$ that represented explicit individual decisions to make zines, outside of the constraints or expectations of a community. Some saw it as a mode of expression (such as R.17) and others positioned themselves within the wider discourse of finding or asserting 'voice' (such as R.8). Whilst these respondents were quite 
definitive about their personal reasons, there were no respondents who made the same explicit assertions about making zines for the community. The interspersion of the possessive terms and personal rationales alongside the collective notion of community offers more evidence that the frames of participation and decision making are porous.

'I would say that zine making is a curious mixture of being part of a large, vibrant community and being something of a solitary, obsessional personal quest.' (R.5)

'Many zine readers are also zine makers, and zines represent the very individual and undiluted creativity of their creators. Reader or creator or both, it's the thriving individuality within the scene that should be appreciated, encouraged and respected.'

The arguments addressing zine making as an individual pursuit are addressed in the literature, where concepts such as personal expression are critical to the individuals decision to make zines (Harris, 2004; Reger, 2007). 'Personal $n=4$ ' and 'express $n=4$ ' were terms used by the respondents to describe theirs (and in one instance, others) motivations for making zines. Another two respondents clarified this further by arguing that in fact these aspects of personal expression were in fact political actions aligned with the transformative capacity or requirements of a community;

'I do strongly believe in the motto that "the personal is political", especially so when I'm talking about my experiences as a male-identifying heterosexual transvestite - it's hard for me NOT to do something political, given that identity. I'm not actively a part of a collective, though, apart from being left-wing politically, as well as a vegetarian.' (R.20)

\section{An Anglophone Note}

Another interesting observation (perhaps a quirk) in the data was from the two zine makers who made zines in languages other than English (Dutch and Spanish). In both cases the zine makers noted that they had little or no contact with other zine makers suggesting that there were less zines made in their language than in English so there was a reduced opportunity for engagement. In neither case did this paucity of interaction impact on their decision to make zines. 


\section{Conclusion}

The responses in this study represented an engagement with parts of a complex and arguably discursive and fragmented community of zine makers. To that extent, it was difficult to isolate the actions and decisions of individuals (in this case to make zines) from their interactions with readers, their community and with zines themselves. Guba and Lincoln (1994) suggest that it is impossible to separate humans from the actions and activities they are engaged in, whilst Crotty(1998) takes this argument one step further by assuming that the 'basic generation of meaning is always social, arising in and out of interaction with a human community' (Crotty, 1998, p. 9). The data analysis identified a relatively small number of instances $(n=6)$ where solely personal, individual reasons were explicitly referenced as motivation for making zines. There were no explicit examples where the community was the sole reason for deciding to participate in zine making. In some ways this difference can be rationalised by the personal nature of how community is defined by zine makers. However, the data analysis offered a number of examples where despite the community being referenced there was specificity about the benefit of being part of a community, as opposed to the impact of the zine on the community. Ownership and identification as responses asserted primacy over involvement and membership.

Despite Duncombe's(1997) assertion that zine making as a practice is socially constructed and community owned, the data suggests that what constitutes zine making as a practice is constructed individually and is then used by zine makers to aggregate their own community of like-mindedness. The engagement zine makers seek from the community is often a passive one, validation and vindication of opinions, feedback or imitation (becoming a zine maker themselves). It suggests that motivations such as ego, appreciation and reputation may sit at the core of the decision to make zines. Certainly, the cliché that 'if a trees falls in the forest, does anyone hear?' can be applied to zine making. Would zine makers participate if there was no community of readers? Yorke(2000) argues that zine making as an art form is dwindling (or already dead as he states) because of its own 'unfeasibility', considering the nature of zine participation as one where new makers are spawned primarily from old readers. The respondents clearly identified the need for a zine to have an audience and that engaging readers was a central part of their practice, with a number arguing that a community cannot be formed from zine makers alone. 
The motivations for an individual's decision to participate in zine making are complex and to assert that participation is solely connected to the need for an audience in order to validate opinion or expression is far too simplistic a notion in the face of data collected. If a zine maker chooses to make their zine in order to engage with others in a social network, then the role of sharing information, experiences and expertise becomes secondary to the formation and membership of that community. In this instance the nature of the information being exchanged changes towards facilitating communication and how to form and maintain connections. But in reality, what is the 'thing' that the community is forming around? Does the zine become secondary to talking about zines? This disconnection between practice and interaction poses a further question; what happens to the zine makers that are excluded from these communities, the 'disillusioned outsiders'? Do they coalesce into an entirely new and different form of zine community with their own connections and boundaries that seek to link them together? Or do they move away from zine making into a different form of practice? These questions are critical to ascertaining the viability of zine making as a practice. Understanding how communities operate when they are formed is only part of the puzzle. The more cogent observations may evolve from understanding why zine communities' form and the information requirements and practices that direct and shape their structure.

Whilst the data represents potentially a relatively small sample of zine makers, the spread of context and content affords the opportunity to make some significant general observations. Firstly, there is a clear difference in terms of the perspectives that zine maker have around the role of the community in the decision making process. Again, the 'chicken and egg' metaphor seems apropos. The literature suggests that the consideration or activity of the community more often came before the decision to make zines. Potential zine makers were exposed to zines that they liked on topics that interested them, and within the context of either being a member of that community or desire to become one, an individual then chose to make a zine. Where the evidence suggested that personal reasons for participation were at play, then the cases offered within research discourse suggested that a desire to say something, share something or tell a story informed the decision to make a zine. The data set analysed did not present significant evidence to suggest either of these frames were universally true. What emerged was a less altruistic and more self-oriented spectrum of motivations for zine making participation. People made zines for reasons that meant something personally to them or provided them with benefit or societal (but not monetary) gain. They engaged with the 
community for the benefits it afforded them as zine makers (feedback, inspirations, and friendship). It would be disingenuous to suggest that these motivations for participation are selfish, because there were a number of demonstrative examples where the concerns and interests of the reader were at the heart of the practice of the zine maker. However, we need to separate the practice of zine making and the decision to participate. The respondents here clearly argued that they made zines because they wanted, needed or were compelled to for personal reasons. Whilst it is clear that some zine makers will make zines whether there is a reader or not, the personal motivation of meeting new people, making friends or engaging with other zine makers is predicated on the fact that people continue to make zines. This suggests that for zines to survive there needs to be a focus on developing and enhancing readership communities as both a market for the zine maker and a potential pool of new and emerging practitioners. 


\section{References}

Angel, J., \& Kucsma, J. (Eds.). (2004). The Zine Yearbook (Vol. 8). Brooklyn: Become the Media.

Bartel, J. (2004). From A to Zine: Building a winning zine collection in your library. Chicago: American Library Association.

Blazek, E. A. (2006). A Woman's Place, An Authentically Feminist Zine University of North Dakota.

Boellstorff, T. (2004). Zines and Zones of Desire: Mass-Mediated Love, National romance, and Sexual Citizenship in Gay Indonesia. The Journal of Asian Studies, 63(2), 367402.

Brown, J. S., \& Duguid, P. (1996). The social life of documents. First Monday, 1(1). Retrieved from http://firstmonday.org/htbin/cgiwrap/bin/ojs/index.php/fm/article/viewArticle/466/387

Chavis, D. M., Hogge, J. H., McMillan, D. W., \& Wandersman, A. (1986). Sense of community through Brunswik's lens: A first look. Journal of Community Psychology, 14(1), 24-40.

Chidgey, R. (2006). The Resisting Subject: Per-zines as life story data. University of Sussex Journal of Contemporary History, 10, 1-13.

Chu, J. (1997). Navigating the Media Environment: How Youth Claim a Place Through Zines. Social Justice, 24(3), 71-85.

Cogan, B. (2007). "Was He Safe or Was He Out?": Sports Zines and Questions of Authenticity. The Journal of Popular Culture, 40(5), 808-830.

Collins, D. (1999). No Experts Guaranteed! Do-It-Yourself Sex Radicalism and the Production of the Lesbian Sez Zine "Brat Attack". Journal of Women in Culture and Society, 25(1), 65-89.

Crotty, M. (1998). The foundations of social research: Meaning and perspective in the research process: Sage Publications Ltd.

Culton, K. R. (2007). From Zines to the Internet: An Exploration of Communication Practices in a DiY Punk Scene. Paper presented at the Annual meeting of the American Sociological Association. Retrieved from http://www.allacademic.com/meta/p183110_index.html

DeSousa, K. (2008). MCA Zine Fair Program. 
Duncombe, S. (1997). Notes from Underground: Zines and the Politics of Alternative Culture. London: Verso.

Dunn, K., \& Farnsworth, M. A. Y. S. (2012). "We ARE the Revolution”: Riot Grrrl Press, Girl Empowerment, and DIY Self-Publishing. Women's Studies, 41(2), 136-157.

Eichhorn, K. (2001). Sites Unseen: Ethnographic Research in a Textual Community. Qualitative Studies in Education, 14(4), 565-578.

Eismann, S., Jiménez, H., \& Zobl, E. (2008). Wolverette: "Taking you and your GRRRLness Seriously" - An interview with Dodo B. from: Tübingen, Germany. Retrieved 20th August, 2009, from http://grrrlzines.net/interviews/wolverette.htm

Ferris, M. B. (2001). Resisting Mainstream Media: Girls and the Act of Making Zines. Canadian Woman Studies, 20/21(4/1), 51-55.

Freedman, J. (2009). Grrrl Zines in the Library. Signs: Journal of Women in Culture and Society, 35(1), 52-59.

Gordon, J. (2012). Sexual Assault Support zines as a Pedagogy of Hope. Thinking Gender Papers. Retrieved from http://escholarship.org/uc/item/3j65b7v9

Gottlieb, J., \& Wald, G. (2006). Smells Like Teen Spirit: Riot grrrls, revolution, and women in independent rock. In A. Bennett, B. Shank \& J. Toynbee (Eds.), The Popular Music Studies Reader. Oxford: Routledge.

Grant, D. (2009). The Zine Lives: Why the 90s Aren't As Dead As You Think. Retrieved 5th August, 2009, from http://www.jossip.com/the-zine-lives-why-the-90s-arent-as-deadas-you-think-20090218/

Guba, E. G., \& Lincoln, Y. S. (1994). Competing paradigms in qualitative research. Handbook of qualitative research, 2, 163-194.

Gunderloy, M. (1990). Zines: Where the Action Is: The Very Small Press in America. Retrieved 5th August 2009, from http://zinewiki.com/Zines:_Where_the_Action_Is:_The_Very_Small_Press_in_Ameri ca

Guzzetti, B. J., \& Gamboa, M. (2004). Zines for social justice: Adolescent girls writing on their own. Reading Research Quarterly, 39(4), 408-436.

Hamilton, J. (2000). Alternative Media: Conceptual Difficulties, Critical Possibilities. Journal of Communication Inquiry, 24(4), 357-378.

Harris, A. (2003). gURL scenes and grrrl zines: the regulation and resistance of girls in late modernity. Feminist Review, 75, 38-56. 
Harris, A. (2004). Jamming Girl Culture: Young Women and Consumer Citizenship. In A. Harris (Ed.), All about the girl: culture, power, and identity (pp. 163-172). New York: Routledge.

Holtzman, B., Hughes, C., \& Van Meter, K. (2007). Do It Yourself... and the Movement Beyond Capitalism. In S. Shukatis, D. Graeber \& E. Biddle (Eds.), Constituent Imagination: Militant Investigations, Collective Theorization. Oakland: AK Press.

Hsieh, H. F., \& Shannon, S. E. (2005). Three approaches to qualitative content analysis. Qualitative Health Research, 15(9), 1277-1288.

Jackson, M.-R., Herranz, J., \& Kabwasi-Green, F. (2003). Art and Culture A Framework for Measurement, . Washington DC: The Urban Institute.

Lacey, A. (2005). Networked Communities: Social Centers and Activist Spaces in Contemporary Britain. Space and Culture, 8(3), 286-301.

Lankshear, C., \& Knobel, M. (2010). DIY Media: A contextual background and some contemporary themes. In M. Knobel \& C. Lankshear (Eds.), DIY media: creating, sharing and learning with new technologies (Vol. 44, pp. 1-26): Peter Lang Publishing Incorporated.

Licona, A. C. (2005). (B)orderlands' rhetorics and representations: the transformative potential of feminist third-space scholarship and zines. NWSA Journal, 17(2), 104129.

Licona, A. C. (2012). Zines in Third Space: Radical Cooperation and Borderlands Rhetoric. New York: State University of New York Press.

Livingston-Webber, J. (1994). How Sassy Are Grrrl Zines? Paper presented at the Conference on College Composition and Communication.

lolagouine. (2009). It's Raining Dykes (Il pleut des gouines): A Queer and Feminist Comix Zine. [Article]. Signs: Journal of Women in Culture \& Society, 35(1), 67-74.

Malekoff, A. (2010). The Do-It-Yourself (DIY) Movement and Young People with Serious Physical Illnesses Who Support Building Communities of Care. Social Work With Groups, 33(4), 304-307.

Matthes, J., \& Kohring, M. (2008). The content analysis of media frames: Toward improving reliability and validity. Journal of Communication, 58(2), 258-279.

Milner, J. (2002). Arts Impact: Arts and culture in the community. Performing Arts \& Entertainment in Canada, 34(1), 11-12. 
Moore, R. (2007). Friends Don't Let Friends Listen to Corporate Rock: Punk as a Field of Cultural Production. Journal of Contemporary Ethnography, 36(4), 438-474.

O'Neil, M. (2004). Exclusion and inclusion in personal media networks. Paper presented at the Mobile Boundaries/Rigid Worlds: Proceedings of the 2nd Annual Conference of the Centre for Research On Social Inclusion, Sydney, Australia.

Payne, J. G. (2009). Feminist media as alternative media? A literature review. Interface: A Journal for and about Social Movements, 1(2), 190-211.

Peace, E. (2007). Future Melbourne: Artist Run Spaces/ Artist Run Initiatives: Sticky and Melbourne's Zine Culture. Future Melbourne Retrieved 22nd July 2009, from http://www.stickyinstitute.com/zineopedia/FUTURE\%20MELBOURNE.pdf

Piepmeier, A. (2008). Why Zines Matter: Materiality and the Creation of Embodied Community. American Periodicals, 18(2), 213-238.

Piepmeier, A. (2009). Girl Zines: Making Media, Doing Feminism. New York: New York University Press.

Poletti, A. (2005). Self-Publishing in the Global and Local: Situating Life Writing in Zines. Biography, 28(1), 183-192.

Poletti, A. (2008). Intimate ephemera: Reading young lives in Australian zine culture. Melbourne: Melbourne University Press.

Radway, J. (2011). Zines, Half-Lives, and Afterlives: On the Temporalities of Social and Political Change. PMLA, 126(1), 140-150.

Rauch, J. (2004). Hands-on Communication: Zine Circulation Rituals and the Interactive Limitations of Web Self-Publishing. Popular Communication, 2(3), 153-169.

Rauch, J. (2007). Activists as interpretive communities: rituals of consumption and interaction in an alternative media audience. Media Culture Society, 29(6), 994-1013.

Reger, J. (2007). Where Are the Leaders? Music, Culture, and Contemporary Feminism. American Behavioral Scientist, 50(10), 1350-1369.

Richardson, A. (1996). Come on, join the conversation!:Zines as a medium for feminist dialogue and community building. Feminist Collections, 17(3-4), 10-13.

Rosenberg, J., \& Garafolo, G. (1998). Riot Grrrl: Revolutions from within. Signs, 23(3), 809841.

Runte, R. (2000). Why Publish? A Sociological Analysis of Motivation in Youth Avocational Subcultures. Broken Pencil, 1, 12-15. 
Schilt, K. (2003a). " I'll Resist with Every Inch and Every Breath": Girls and Zine Making as a Form of Resistance. Youth \& Society, 35(1), 71-97.

Schilt, K. (2003b). "A Little Too Ironic": The Appropriation and Packaging of Riot Grrrl Politics by Mainstream Female Musicians. Popular Music and Society, 26(1), 5-16.

Schilt, K. (2004). "Riot Grrrl Is...": The Contestation over Meaning in a Music Scene. In A. Bennett \& R. A. Peterson (Eds.), Music Scenes: Local, Translocal and Virtual. Nashville: Vanderbilt University Press.

Sellie, A. (2005). A Do-It-Yourself Zine Definition. Counterpoise, 9(3), 8-9.

Sinor, J. (2003). Another Form of Crying: Girl Zines as Life Writing. Prose Studies, 26(1), 240-264.

Spencer, A. (2005). DIY: the rise of lo-fi culture. London: Marion Boyers.

Steele, J. (2006). Why I write cookzines. Broken Pencil, (33). Retrieved from http://www.brokenpencil.com/features/features.php?featureid=102

Stern, S. (2001). Sexual selves on the World Wide Web: Adolescent girls' home pages as sites for sexual self-expression. In J. D. Brown, J. R. Steele \& K. Walsh-Childers (Eds.), Sexual Teens, Sexual Media - Investigating Media's Influence on Adolescent Sexuality (pp. 265-286). London: Routledge.

Stoddart, R. A., \& Kiser, T. (2004). Zines and the Library. Library Resources and Technical Services 48(3), 191-198.

Sutton, L. A. (1999). All Media Are Created Equal Do-lt-Yourself Identity in Alternative Publishing In M. Bucholtz (Ed.), Reinventing Identities : The Gendered Self in Discourse. Cary: Oxford University Press.

Triggs, T. (2006). Scissors and Glue: Punk Fanzines and the Creation of a DIY Aesthetic. Journal of Design History, 19(1), 69-83.

Wagg, H. (2003). MEDIAte This! Positioning Communications in Riot Grrrl Subcultural Formation. Journal for the Arts, Sciences and Technology, 01(2), 19-24.

Ware, I. (2003). An Introduction to Zines and Their Definition. Paper presented at the Critical Animals Conference.

Weber, R. P. (1990). Basic content analysis. Quantitative applications in the social sciences (Vol. 49). Newbury Park, California: Sage.

Wray, J., \& Steele, J., R. (2001). Girls in Print: Figuring Out What It Means To Be a Girl. In J. Brown, D., J. Steele, R. \& K. Walsh-Childers (Eds.), Sexual teens, sexual media: investigating media's influence on adolescent sexuality. London: Routledge. 
Wrekk, A. (2005). Stolen sharpie revolution: A DIY zine resource. Portland, OR: Microcosm.

Yorke, C. (2000). Zines are Dead: the Six Deadly Sins That Killed Zinery. Broken Pencil, (12), 18-19. Retrieved from http://www.brokenpencil.com/features/feature.php?featureid=46

Young, S., \& Collins, S. (2010). A View from the Trenches of Music 2.0. Popular Music and Society, 33(3), 339 - 355.

Zobl, E. (2003). Writing and distributing whatever I want! . Retrieved 24th November 2008, from http://www.grrrlzines.net/interviews/moonrocket.htm

Zobl, E. (2004a). Persephone is Pissed! Grrrl Zine Reading, Making, and Distributing Across the Globe. Hecate, 30(2), 156-175.

Zobl, E. (2004b). The Power of Pen Publishing: International Grrrl Zines and Distros. Feminist Collections, 26(1), 20-24.

Zobl, E. (2009). Cultural Production, Transnational Networking, and Critical Reflection in Feminist Zines. Signs: Journal of Women in Culture and Society, 35(1), 1-12.

Zobl, E., \& Jiminez, H. (2008). Park it up your arse: "This zine is for all us 'weirdos'!" An interview with Leigh Ann Retrieved 20th January, 2012, from http://www.grrrlzines.net/interviews/parkitupyourarse.htm 